\title{
Essence of PTEN: a Broad-Spectrum Therapeutic Target in Cancer
}

\author{
Mukta Raghav ${ }^{1}$ (D), Varruchi Sharma ${ }^{2}$ (D), Mayank Chaudhary ${ }^{1}$, , Hardeep Singh Tuli ${ }^{1}$, Adesh K. \\ Saini $^{1,3(D)}$, Anil K. Sharma ${ }^{1, *(D)}$ \\ Department of Biotechnology, Maharishi Markandeshwar (Deemed to be University), Mullana (Ambala), Haryana, India \\ Department of Biotechnology, Sri Guru Gobind Singh College Sector-26, Chandigarh (UT) India \\ Maharishi Markandeshwar University, Kumarhatti (Solan), Himachal Pradesh, India \\ Correspondence: anibiotech18@gmail.com;
}

Scopus Author ID 55693618000

Received: 18.08.2020; Revised: 11.09.2020; Accepted: 12.09.2020; Published: 15.09.2020

\begin{abstract}
The levels of protein tyrosine phosphorylation within a cell is regulated by protein tyrosine kinases and protein tyrosine phosphatases. These protein tyrosine phosphatases (PTP) can act both as positive and negative regulators during cell cycle progression and signal transduction. Phosphatase activity is shown by Phosphatase and Tensin homolog (PTEN) protein encoded by PTEN gene localized on human chromosome 10. Earlier findings established the role of PTEN as a tumor suppressor in Cowden's disease, where PTEN mutations resulted in disease outcomes. Subsequent studies found the role of PTEN mutations in various human cancers, making it one of the vastly studied tumor suppressor genes. The current review has been planned to get a deeper insight into the potential role of PTEN in a variety of physiological processes involved in normal development like cell growth, migration, and differentiation along with the factors, regulation, and underlying mechanism.
\end{abstract}

Keywords: PTEN; Cancer; cell proliferation; Cell Cycle regulation; intracellular; cytotoxic; tumor suppression; Phosphorylation.

(C) 2020 by the authors. This article is an open-access article distributed under the terms and conditions of the Creative Commons Attribution (CC BY) license (https://creativecommons.org/licenses/by/4.0/).

\section{Introduction}

Protein tyrosine kinase and protein tyrosine phosphatase regulate the level of protein tyrosine phosphorylation within a cell. These protein tyrosine phosphatases (PTP) can act both as a positive and negative regulator during cell cycle progression and signal transduction [1]. A large number of proteins are included in the PTP superfamily, which also comprises of dual specific phosphatases. Phosphatase activity similar to such dual phosphatases is shown by Phosphatase and Tensin homolog (PTEN) protein encoded by PTEN gene, which is localized on human chromosome 10. The role of PTEN as a tumor suppressor was initially found in Cowden's disease, where PTEN mutations resulted in disease outcomes [2]. Subsequent studies had found the role of PTEN mutations in various human cancers, making it one of the vastly studied tumor suppressor genes [3].

PTEN plays a major role in processes involved in normal development like cell growth, migration, and differentiation by inhibiting signals transduced by phosphotidylinositol-3kinase (PI3K) [4]. PI3Ks comprises of lipid kinases that activate various signaling pathways through phosphorylation. These are grouped in 3 classes on the basis of substrate preference and sequence homology [5]. Class I PI3Ks can either be activated by receptor tyrosine kinases (RTKs) or by G-Protein coupled receptors (GPCRs), which can further activate 
serine/threonine kinase AKT and other downstream pathways. It had been found that genetic alteration in several proteins in PI3K pathway culminates into cancer. Some evidence suggested that constituents of PI3K pathway are highly suitable for pharmacologic intervention and one of the most alluring targets for therapeutic intervention in cancer. Further, the functioning of PTEN as $\mathrm{PIP}_{3}$ 3'-phosphatase turns off PI3K pathway, thus renders its tumor suppressor activity (Fig.1). Therefore, the loss of PTEN activity could result in uncontrolled signaling through PIK3 pathway leading to cancer [6]. In addition to PTEN, SHIP-2 functions as $\mathrm{PIP}_{3} 5^{\prime}$-phosphatase to negatively regulate $\mathrm{PI} 3 \mathrm{~K}$ and protein kinase $\mathrm{B}$ (PKB) pathway, as seen in glioblastoma multiform brain tumors [7,8]. Recently, many functions of PTEN independent of PI3K/AKT signaling pathway are also explored [9]. This review, therefore, covers the role of PTEN both as a tumor suppressor and metabolic regulator, including its downstream targets. Additionally, epigenetic regulation of PTEN is also discussed.

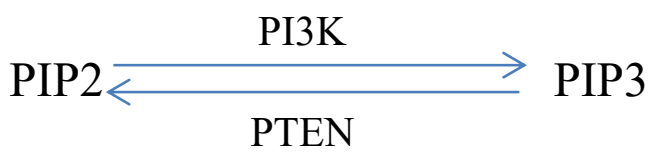

Figure 1. The antagonistic function of PI3K and PTEN.

The protein encoded by PTEN comprises of 403 amino acid residues with a structurally significant catalytic phosphatase domain and $\mathrm{C} 2$ domain. Both $\mathrm{N}$ and $\mathrm{C}$-terminus of PTEN have crucial sequences as the $\mathrm{N}$-terminus sequence is responsible for the binding of the protein to membrane lipids, and C-terminus contains a binding motif involved in protein-protein interaction [10]. PTEN possesses both lipid and protein phosphatase activity in-vitro [11], whereas, under in-vivo conditions, mostly lipid phosphatase activity is observed $[12,13]$.

\section{Diverse roles of $P T E N$ in relation to cancer}

\subsection{Role of PTEN in cell cycle regulation.}

A cell cycle is a coordinated event consisting of four distinct phases (G1, S, G2, and M). PTEN plays a significant role in normal cell cycle regulation as it controls the re-entry of cells in cell cycle phases resting in $\mathrm{G}_{0}$ stage. Moreover, it also acts as a regulatory switch from G1/S and G2/M transition. Various studies marked PTEN as an important component of multiple checkpoints to prevent uncontrolled proliferation (Fig. 2). Abnormal development of the cephalic region was found in PTEN mutant embryos [14-16]. In addition to this, PTEN mutants also showed decreased sensitivity to apoptosis.

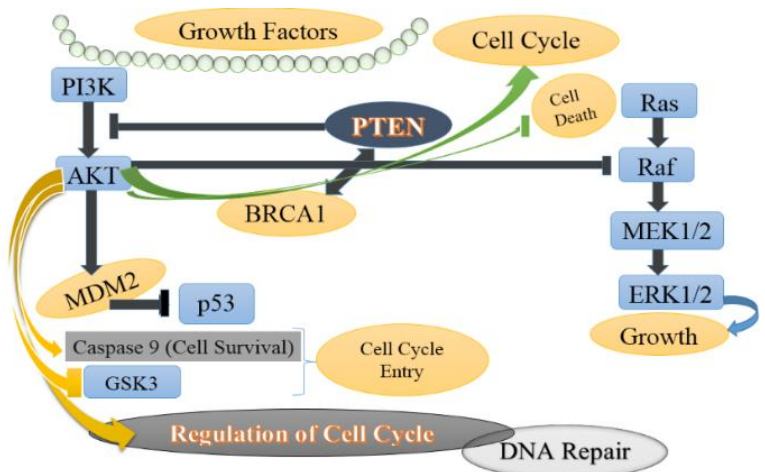

Figure 2. Schematic representation of PTEN involved in cell signaling through the participation of other tumor suppressors such as TP53, MDM2, and BRCA1 performing a variety of physiological functions such as cell proliferation, DNA repair, and regulation of cell cycle, etc. 


\subsubsection{Role in G1-S transition.}

Entry and progression through G1 depend upon cell type and context where each cell undergoes different signals and developmental programs with differential risk of transformation [17]. Progression of the cell through different stages of the cell cycle is mediated by cyclin-CDK complex. Cyclin dependant kinase (CDK) requires cyclin for catalytic competence and different cyclin-CDK complex works during different stages of the cell cycle. In addition to the role of small inhibitory proteins like Inhibitors of CDK4 (INK4), CDK interacting protein/Kinase inhibitory protein (CIP/KIP) [18], and ubiquitin-mediated proteolysis mechanism[19], PTEN also regulates G1 progression and G1/S transition. Progression of the cell cycle with accelerated G1/S transition was seen due to the loss of PTEN in embryonic stem cells[20]. Expression of p27 Kip1 induced by PTEN showed a reduction in CDK2 activity inhibiting G1/S transition[21]. This was further proved that PTEN induced G1 arrest requires p27 Kip1. Collateral deletion of PTEN and $p 27^{\text {Kipl } 1}$ led to the development of prostate cancer, highlighting their importance in tumor suppression [22,23]. Besides PTENp27 Kip1 pathway, certain other regulators are also involved in PTEN mediated control of G1 phase[24]. The role of PTEN in cell cycle regulation has been elucidated in Figure 3.

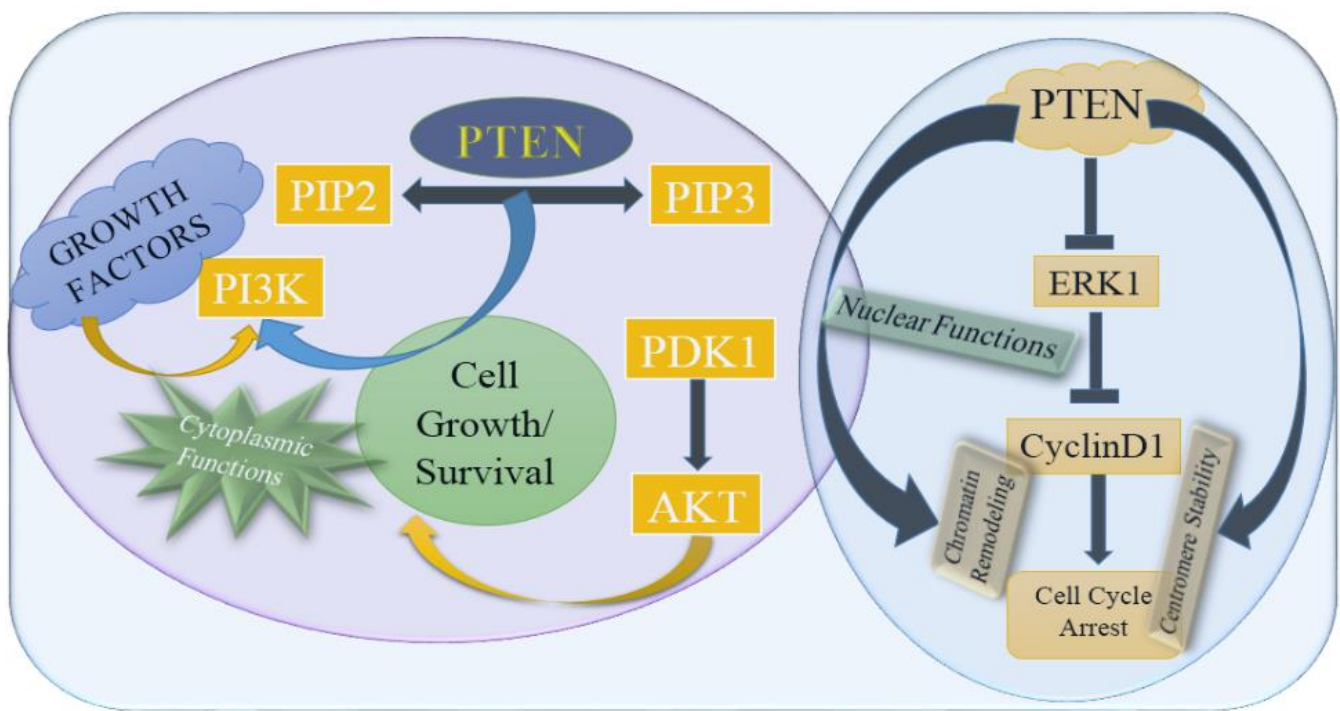

Figure 3. Role of PTEN in cell cycle regulation. PTEN signaling at the nuclear and cytoplasmic levels has been shown with a coordinating role in the facilitation of diverse mechanisms in cell cycle regulation. The PTEN localization at the subcellular levels is a determinant of its functional aspects. At the cytoplasmic level, there is a downregulation of AKT, along with an increase in the levels of other associated components leading to apoptosis. While at the nuclear level, PTEN downregulates ERK, increasing the cyclin D1 levels leading to cell cycle arrest, overall genomic stability, and increased apoptosis.

Along with cytoplasmic localization, PTEN is also found in the nucleus to induce G1 arrest independently [25]. Oxidative stress causes PTEN phosphorylation resulting in nuclear accumulation by inhibiting nuclear export[26]. Regulation of G1 phase by PTEN is mediated by the upregulation of $\mathrm{p} 27{ }^{\mathrm{Kip} 1}$ by cytoplasmic PTEN and downregulation of cyclin D1 by nuclear PTEN [27]. Nuclear PTEN can further cause acetylation of p53 in response to DNA damage resulting in G1 arrest[28]. G1 arrest can also be mediated by nuclear PTEN in combination with SPRY2 (Sprouty RTK Signaling Antagonist 2)[29]. Thus, PTEN inhibits premature progression to $\mathrm{S}$ phase and also regulates DNA fork progression during $\mathrm{S}$ phase. PTEN recruits damage response proteins in case of replication stress [30]and further interacts with single-strand DNA binding protein and DNA helicase for stabilization of the replication 
fork [31]. The loss of PTEN, therefore, results in replication errors enhancing genomic toxicity [32].

\subsubsection{Role in G2-M transition.}

The involvement of PTEN in G2-M transition was found in PTEN deficient cells, which showed the accelerated transition from $\mathrm{G} 2 / \mathrm{M}$ to $\mathrm{G} 1$ in response to radiation-induced DNA damage [33]. This was further validated as PTEN null embryonic stem cells showed premature exit from G2 on radiation treatment [34]. Phosphorylation of PTEN by CHK1 (Checkpoint kinase 1) can cause cells with hindered DNA replication to enter G2/M[35]. Inhibition of Notch signaling and dephosphorylation of PTEN can result in prometaphase arrest preventing the progression of the cell cycle [36]. PTEN can also be dephosphorylated by TOPK (lymphokineactivated killer T cell-originated protein kinase) to control mitotic entry [37]. PTEN further interacts with TOP2A (DNA topoisomerase II $\alpha$ ) at the decatenation checkpoint in G2 phase for removal of entangled DNA before mitotic entry [38]. During mitosis, loss of PTEN affects the integrity of centrosomes and mitotic spindle, resulting in misalignment of chromosomes, variable ploidy, and tumorigenesis [39]. These mitotic defects can be mediated by increased expression and phosphorylation of PLK1 (polo-like kinase) having oncogenic potential. PTEN controls the expression and phosphorylation level of PLK1, thereby protecting cell division and polyploidy [40,41]. Mutual interaction is set between PTEN and PLK1, where they control each other's phosphorylation to mediate their function during mitotic exit. Similarly, reciprocal regulation between PTEN and $\mathrm{APC} / \mathrm{C}^{\mathrm{CDH} 1}$ (Anaphase promoting complex) promotes the transition from mitotic exit to the next cell cycle. $\mathrm{CDH} 1$ causes $\mathrm{APC} / \mathrm{C}$ induced ubiquitination of PTEN, resulting in PTEN degradation and mitotic exit [42].

\subsection{PTEN as a tumor suppressor.}

PTEN is one of the most frequently mutated genes in human cancers, and germ-line mutations in PTEN can result in rare autosomal dominant inherited cancer syndromes [43]. Somatic mutations occur throughout PTEN gene along with specific hotspots [44]. These mutations can result in increased cell proliferation, reduced cell death, and tumor development. Mutations also lead to loss of PTEN function or reduced levels of PTEN in most of the cases. Genetic inactivation of PTEN is frequently found in glioblastoma, melanoma, endometrial, prostate, colon, and bladder cancer, whereas reduced expression is observed in lung and breast cancer[45-47]. Analysis of $P T E N^{\text {hy/t }}$ mouse model revealed that even subtle reduction in PTEN expression could promote cancer susceptibility in mice, highlighting the importance of PTENcontrolled pathways for tumor development [48]. In addition to genetic mutations in PTEN, epigenetic silencing, transcriptional repression, and post-translational modifications can result in loss of PTEN function.

\section{Metabolic activities}

Though PTEN is globally accepted as a potent tumor suppressor gene its role in metabolic regulation has recently been highlighted by genetic studies. The phosphatase activity of PTEN reduces the level of $\mathrm{PIP}_{3}$ that functions as a critical secondary messenger[49]. Studies on $C$. elegans and Drosophila showed the involvement of PTEN in growth control and metabolism. 


\subsection{Regulation of glucose metabolism.}

Binding of Insulin and Insulin-like growth factors (IGF-1 and IGF-2) to insulin and IGF receptors can either result in direct activation of PI3K or can phosphorylate insulin receptor substrate (IRS) for PI3K activation [50]. Activation of PI3K/AKT results in elevated insulin levels that are sensed by adipocytes and myocytes to initiate glucose uptake. Insulin/PI3K signaling induces membrane trafficking of GLUT4 through phosphorylation of AS160 at Thr642 by serine/threonine kinase AKT in adipocytes [51]. AKT further phosphorylates other targets that are indulged in regulating glucose metabolism. Phosphorylation and inhibition of GSK3 activate glycogen synthase in addition to the regulation of $\beta$-catenin and cell cycle. Liver-specific PTEN null mutation in mice caused phosphorylation of GSK3 and accumulation of glycogen in hepatocytes [52]. Additionally, AKT mediated phosphorylation of FOXO in hepatocytes blocked transcription of glucose-6-phosphatase (G6Pase) and phosphoenolpyruvate carboxykinase (PEPCK) involved in gluconeogenesis [53]. These two enzymes are also transcriptionally repressed through phosphorylation of peroxisome proliferator-activated receptor-gamma co-activator (PGC-1 $\alpha$ ) by AKT [54]. Regulation by AKT and blockage by PTEN mediates the response of metabolic organs like liver, muscle, and adipose tissue to elevated insulin levels [55]. A similar response was seen in mice where PTEN deletion in the liver caused strong down-regulation of PEPCK and moderate down-regulation of G6Pase. Similarly, the deletion of PTEN in mice adipose tissues showed increased insulin sensitivity, increased membrane localization of GLUT4, and resistance to streptozotocininduced diabetes $[55,56]$.

\subsection{Regulation of lipid metabolism.}

Lipid metabolism is also controlled through PTEN-regulated PI3K signaling. PTEN/PI3K/AKT signaling controls the expression of sterol receptor element-binding protein (SREBP) at multiple levels. SREBP functions as a critical master regulator involved in lipogenesis by binding to the promoter of lipogenic enzyme genes. The transcription of SREBP is repressed by the forkhead transcriptional factor, FoxO1 that is a downstream target of AKT [57]. A study demonstrated that induction of SREBP1 transcription is also dependant on TORC1 activity by using rapamycin and siRNA to inhibit mTORC1 $[58,59]$. But contradictory results were seen in TSC1-deficient mice having a defect in mTORC1 signaling [60,61]. SREBP cleavage-activating protein (SCAP) and insulin-induced gene (Insig) controls the processing of SREBP. SCAP mediates cleavage and movement of mature SREBP to the nucleus in response to sterol demand. This action is inhibited by the binding of Insig to SCAP. Interaction of Insig and SCAP is blocked either by inhibition of PI3K/AKT activity or by oxysterols that suppress the expression of Insig-1 [62]. This results in the processing of SREBP that is both mTORC1-dependent and mTORC1-independent [63]. Both TORC1 and FoxO1 are downstream targets of PTEN/PI3K/AKT signaling control SREBP expression and lipogenesis. Additionally, the expression of Fasn by SREBP is inhibited by the binding of Maf1 to the promoter of Fasn. The expression of MAF-1 is itself regulated by PTEN through AKT2 and mTOR [64,65]. These signaling responses were validated in PTEN deficient mice. Loss of $P T E N$ in mice liver resulted in heightened de novo lipogenesis through SREBP induction and Fasn expression. Activation of AKT2 caused elevated lipogenesis, which is both mTOR dependant and independent, and this effect was reversed by the deletion of Akt2 [66]. Additionally, the gain of function of FOXO1 induced lipid synthesis [67]. 


\subsection{Regulation of mitochondrial metabolism.}

The involvement of PI3K/AKT signaling in mitochondrial function has been discovered while elucidating molecular signals underlying "Warburg effects" [50]. The involvement of AKT is found in the inner and outer mitochondrial membrane along with the mitochondrial matrix. Binding of hexokinase II to mitochondrial voltage-dependent anion channel (VDAC) is promoted by AKT that causes phosphorylation of glucose molecules and conversion to ATP at the mitochondrial outer membrane $[68,69]$. Localization of AKT in the inner mitochondrial membrane [70] whereas within the mitochondrial matrix, AKT causes phosphorylation of GSK $3 \beta$ and pyruvate dehydrogenase (PDH) to regulate mitochondrial respiration [71]. Mitochondrial localized AKT further regulates transcription of mitochondrial DNA as a promoter of HMG-CoA contains FOXO-3 response element [72]. Members of PGC1 family function as transcriptional co-activator by binding to estrogen-related receptors (ERRs) for mitochondrial function. ERR $\alpha$ is the best-characterized isoform of ERRs that is abundantly expressed in high oxidative organs [73]. The activity and expression of ERR $\alpha$ are increased by the binding of PGC-1 $\alpha$ [49]. Activation of AKT causes phosphorylation and activation of CREB transcription factor, which in turn induces transcription of PGC-1 upon activation. PGC-1 as a co-activator increases transcription of ERR $\alpha$ to initiate transcription of mitochondrial genes [74].

Additionally, NRF1, which is also involved in the transcription of mitochondrial genes, contains a substrate consensus sequence of AKT where phosphorylation of NRF1 by AKT induced Tfam expression in hepatoma cells [75]. Thus, AKT controls mitochondrial gene transcriptional networks either by direct phosphorylation of FOXO and NRF1 or indirectly by inducing expression of ERR $\alpha$. Similarly, overexpression of NRF1 and AKT imitated the effect of TFAM to overrule ion-induced mitochondrial damage confirming the involvement of $\mathrm{PI} 3 \mathrm{~K} / \mathrm{AKT} / \mathrm{FOXO}$ signaling pathway in the regulation of mitochondrial gene transcription [76,77].

\section{Regulation of PTEN at the post-translational level}

The activity of PTEN can be regulated at genetic, epigenetic, and post-translational levels [78]. PTEN function can be lost partially or completely by genetic alterations occurring due to allelic loss, point, or truncation mutations [79]. Epigenetic alteration includes gene silencing due to promoter hypermethylation [80]. Post-translational modification of PTEN includes phosphorylation, ubiquitination, sumoylation, acetylation, and oxidation (Fig. 4).

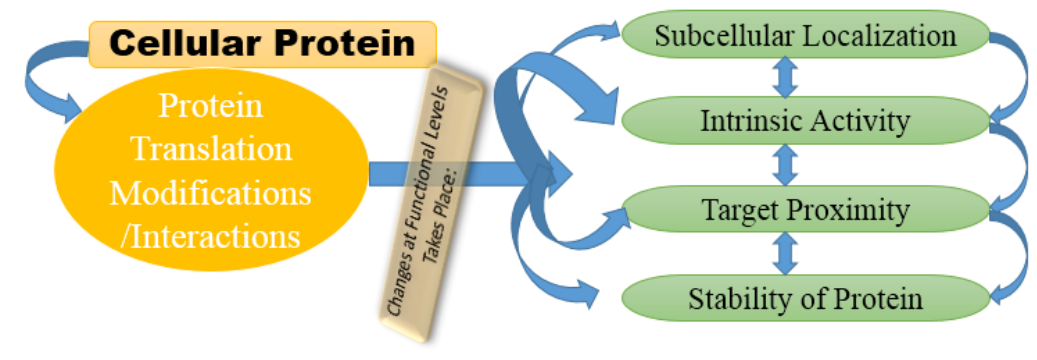

Particular Biological \& Cellular Functions are performed

Figure 4. Post-translational regulation of PTEN. Post-translational regulation of PTEN commands its detailed cellular and biological functions; at cellular levels, specific PTM's/interactions generate biochemically distinctive subpopulations of PTEN, which is having certain biochemical and cellular properties for diverse and dedicated cellular and biological functions. 


\subsection{Phosphorylation.}

Phosphorylation targets $\mathrm{C} 2$ and C-terminal domains of PTEN to modulate its activity [81-82]. Phosphorylation leads to a closed conformational state of PTEN, resulting in inactivation and increased stability. Increased phosphorylation causes reduced expression of PTEN, as seen in the case of gastric cancer $[83,84]$. PTEN in non-phosphorylated open state conformation shows increased association with the membrane [85]. So, dephosphorylation of PTEN is necessary before binding to membrane proteins._PTEN phosphorylation can be caused by multiple kinases that target specific sites. Abnormal regulation of PTEN by multiple cancerspecific kinases is shown in Table 1.

\begin{tabular}{l|l|l|l}
\multicolumn{4}{c}{ Table 1. Abnormal PTEN regulation by multiple cancer-specific kinases. } \\
$\begin{array}{l}\text { Specific } \\
\text { Kinases }\end{array}$ & $\begin{array}{l}\text { Sites of PTEN targeted through } \\
\text { phosphorylation }\end{array}$ & Abnormal Effects & Tumor Type \\
\hline CK2 & Ser 370, Ser 380,Ser 385, Thr 382, & $\begin{array}{l}\text { Decrease in phosphatase } \\
\text { activity }\end{array}$ & $\begin{array}{l}\text { Lymphoblastic Leukaemia, } \\
\text { Endometrial carcinoma }\end{array}$ \\
\hline RAK & Tyr 336 & $\begin{array}{l}\text { Irregularity in function and } \\
\text { degradation of PTEN }\end{array}$ & Breast Cancer \\
\hline PLK1 & Thr 366,Ser 370,Ser 380, & $\begin{array}{l}\text { Inactivation } \\
\text { degradation of PTEN }\end{array}$ & Prostate Cancer \\
\hline LKB1 & Ser 380,Ser 385, Thr 382, Thr 383 & Inactivation of PTEN & $\begin{array}{l}\text { Lung Squamous cell } \\
\text { carcinoma, Ovarian cancer }\end{array}$
\end{tabular}

PTEN is phosphorylated by glycogen synthase kinase-3 $\beta$ (GSK3 $\beta$ ) at Ser362 and Thr366. GSK3 $\beta$ mediated phosphorylation of PTEN can function as a negative feedback loop of the PI3K signaling pathway [86]. Mutation at one of the phosphorylation sites (Ser385) promoted dephosphorylation events to regulate PTEN function. In addition to this, the interaction between $\mathrm{COOH}$-terminal and CBRIII motif of the $\mathrm{C} 2$ domain was identified, and the auto-inhibitory role of $\mathrm{COOH}$-terminal on PTEN membrane recruitment and phosphatase activity was suggested [87]. Moreover, RhoA-associated protein kinase (ROCK) mediated phosphorylation can lead to membrane translocation of PTEN [88]. The catalytic subunit of PI3K, p110 inactivates PTEN via RhoA and ROCK pathway through increased tyrosine phosphorylation of PTEN [89].

Similarly, Src family tyrosine kinase, FRK (Fyn-related kinase), promotes phosphorylation on Tyr336, causing PTEN stability [90]. The activity and stability of PTEN depend upon the site of phosphorylation and kinase involved. Phosphorylation of $\mathrm{C} 2$ domain of PTEN causes increased membrane affinity with decreased degradation. On the other hand, phosphorylation of the C-terminal domain caused a conformational change and increased stability with decreased activity and membrane targeting [79].

\subsection{Ubiquitination and Sumoylation of PTEN.}

PTEN levels can also be affected by downregulation through the ubiquitin/proteasome pathway. Loss of PTEN function due to ubiquitin-mediated degradation is considered to be the cause of non-small cell lung carcinoma [91]. Overexpression of NEDD4-1 induces ubiquitination of PTEN at Lys13 and 289 causing ubiquitin-mediated PTEN degradation [92]. Some reports indicated NEDD4-1 mediated PTEN regulation in the bladder, gastric, and colorectal cancers, but the deletion of NEDD4-1 in mice and cultured cells does not prevent ubiquitination of PTEN [93]. This indicated role of additional E3 ligases like WWP2 (WW domain-containing protein 2) and X-linked inhibitor of apoptosis protein (XIAP) in regulating PTEN protein levels [94]. Polyubiquitination of PTEN results in degradation and loss of tumor 
suppressor activity, whereas monoubiquitination causes nuclear transport and genomic stability. PTEN contains two PEST sequences that are a unique mark of ubiquitin-mediated degraded proteins [95]. Recently additional ubiquitination site (Lys66) was found in PTEN, which showed a major role in PTEN stability [96]. Inhibition of proteasome-mediated PTEN degradation is considered as a therapeutic approach for PTEN stability [97]. Deubiquitylase HAUSP/USP7 (Herpesvirus associated ubiquitin-specific protease) can reverse the monoubiquitination of PTEN, preventing nuclear import [98]. Mislocalization of PTEN is considered as a cause of central nervous system tumors and lymphomas [99].

Similarly, sumoylation mediated by SUMOs (Small ubiquitin-like modifiers) regulates PTEN activity through covalent attachment to the C2 domain of PTEN at Lys254 and 266. Sumoylation facilitates the binding of PTEN to the plasma membrane and downregulation of PI3K/AKT pathway, suppressing tumor progression [100]. An additional common site (K289) for SUMO mediated modification and monoubiquitination was found on PTEN. Monoubiquitination results in nuclear localization, whereas sumoylation results in recruitment to the plasma membrane. The exclusion of sunoylated PTEN from the nucleus made cells hypersensitive to DNA damage [101].

\subsection{Acetylation of PTEN.}

Stimulation by growth factors initiates acetylation of PTEN at Lys125 and 128 (K125 and K128) by lysine acetyltransferase 2B (KAT2b)/PCAF (p300-CREB binding protein), reducing catalytic activity of PTEN [102]. PTEN can also be acetylated at the PDZ binding domain (Lys402) by CREB binding protein, which affects the interaction of PTEN with PDZ domain-containing partners. Acetylation of PTEN can be reversed by deacetylase sirtuin 1 as Sirt-1 deficient cells contained hyper-acetylated PTEN [103].

\subsection{Oxidation of PTEN.}

The activity of PTEN depends on the presence of highly reactive cysteine residue in the catalytic site that functions as protein tyrosine phosphatase sensitive to oxidation [104]. The catalytic activity of PTEN is inactivated by oxidation as a result of environmental stress or cellular strategy. Reactive oxygen species (ROS) in the form of $\mathrm{H}_{2} \mathrm{O}_{2}$ can oxidize cysteine to inactivate PTEN. This is done by the formation of a disulfide bond between Cys 124 and Cys 71 [105,106]. The role of ROS in PTEN inactivation was studied [107], where treatment of murine macrophage cell line with lipopolysaccharide and phorbol acetate increased the percentage of inactive oxidized cellular PTEN. Thioredoxin prevents oxidation mediation inactivation of PTEN [105]. Interaction between peroxiredoxin 1 (PRDX1) and PTEN forms the PTENPRDX1 complex that prevents oxidation of PTEN by inhibition of disulfide bond formation [108]. This was evident as incubation of cells with thioredoxin reductase inhibitor (2,4-dinitro1-chlorobenzene) delayed the reduction of oxidized PTEN and overexpression of thioredoxin reductase promoted resumption of tumor suppressor activity of PTEN. Additionally, the activity of PTEN can also be affected by the oxidation of PTEN-binding partners [109]. Increased ROS levels in tumor cells can initiate PTEN inactivation through oxidation and subsequent activation of the PI3K/AKT signaling pathway. The use of ROS scavengers as an approach can enhance PTEN activity against lymphoblastic leukemic cells [79]. 


\section{Transcriptional and post-transcriptional regulation of PTEN}

The regulation of PTEN is also undertaken at transcriptional and post-transcriptional levels. Transcription of PTEN is regulated by several transcriptional factors that include p53, early growth response protein 1 (EGR-1), peroxisome proliferation-activator receptor $\gamma$ (PPAR $\gamma$ ) [50], and active transcription factor 2 (ATF2) [110]. Transcriptional repression of PTEN is promoted by SNAIL and SLUG [111], where these two compete with p53 to bind to the promoter of PTEN. Additionally, transcription of PTEN is regulated by binding of nuclear kappa B (NFkB), AP-1 transcription factor subunit c-Jun, and Notch signaling co-regulatory CBF-1 (C-promoter binding factor-1) to promoter region [112,113].

\section{RNA mediated regulation of PTEN}

Recently, RNA mediated regulation of PTEN is reported through RNA-RNA interaction by microRNAs and long non-coding RNAs. Several miRNAs were found to bind to 3'-UTR of PTEN mRNA. This is supported by the fact that the reduction in PTEN mRNA levels is observed by a simultaneous increase in levels of various miRNAs [114-116]. A sequence similar to PTEN mRNA is shared by long non-coding RNA encoded by PTEN pseudogene transcript PTENP1 [117]. This transcript stabilizes PTEN mRNA by binding to PTEN targeting miRNAs. Negative PTEN regulation is promoted by binding of an antisense transcript of this pseudogene to PTEN promoter [118,119].

\section{Regulation of PTEN by protein-protein interactions}

PTEN activity can be affected by interacting proteins. Most of these interactions are mediated by PTEN C-terminal PDZ-BD and involves interaction with scaffold proteins. These interactions can alter the role of PTEN as a tumor suppressor by causing a change in its conformation, location, and stability [78]. Binding of interacting protein, melanocortin-1 (MC1R) prevents ubiquitination and degradation of PTEN [120]. Similarly, the ubiquitination of PTEN by NEDD4-1 is inhibited by binding of FRK (Fyn-related kinase) to PTEN. PTEN localization can be regulated by interacting proteins that can influence its function and activity. Increased membrane localization of PTEN is influenced by scaffold proteins like $\beta$-arrestins and membrane-associated guanylate kinase inverted 2 (MAGI2). This causes the activation of the phosphatase activity of PTEN [121,122]. PTEN interacts with the adaptor protein NHERF $\left(\mathrm{Na}^{+} / \mathrm{H}^{+}\right.$exchanger regulatory factor) through the PDZ domain to form a ternary complex that prevents activation of the PI3K/AKT pathway [123]. Movement of PTEN towards the cellular membrane is regulated by motor protein myosin $\mathrm{V}$ which enhances its phosphatase activity [124]. Similarly, tumor suppressor activity and stability of PTEN is enhanced after its interaction with mammalian DLG1 (discs large homolog 1) [125]. The lipid phosphatase function of PTEN can also be activated after interaction with p85 [126]. Disruption in p85PTEN binding through mutation in the p85 gene increased PIP3 levels and AKT phosphorylation [127]. Binding of microtubule-associated Ser/The kinase 2 (MAST2) to PDZ motif of PTEN increased PTEN phosphorylation [128]. The lipid phosphatase activity of PTEN is also influenced by other regulators, including PREX2a (PIP3 dependent RAC exchanger factor 2a) [129], SIPL1 (Shank-interacting protein-like 1) [130], and MAN2C1 ( $\alpha$-mannosidase 2C1) [131]. 


\section{Epigenetic alteration of PTEN}

The role of epigenetics in PTEN expression has been proposed where promoter methylation suppressed PTEN expression in various types of cancer [132]. Methylation is mostly related to transcriptional repression, but PTEN transcription is not downregulated by promoter methylation under all conditions. This condition was discovered in patients with Cowden syndrome (CS) and Cowden like syndrome (CLS) lacking PTEN mutations [133]. PTEN promoter hyper-methylation showed no detectable effect on PTEN expression in such patients. However, the expression of another gene, KILLIN sharing PTEN promoter and transcribing in the opposite direction, was affected. This KILLIN gene is the target of p53 and is responsible for p53 induced apoptosis [134]. In addition to this, an important finding showed predominant methylation of PTEN pseudogene (psiPTEN) rather than PTEN in cell lines and tumors [135]. Their investigation showed $98 \%$ identity between both genes, which also covers the subsequent part of PTEN promoter. As a result, such an enormous level of homology challenges the methylation study of the PTEN gene. So, nucleotide differences between both sequences should be critically considered for performing PTEN methylation analysis as results obtained might not reflect the exact methylation status of PTEN.

\section{Conclusion}

The detailed insight into the various regulatory components of the PTEN pathway reveals its multifaceted potential in a variety of physiological processes involved in normal development like cellular growth, migration, and differentiation, along with the factors and regulation. Owing to its tumor suppression, PTEN is a commonly mutated gene, reported in several types of cancers. This gene plays a significant role in the regulation of cell growth, survival, proliferation, genomic stability, and cell motility as well. Loss of PTEN activity is a major troublesome that hinders in identifying the clinical aspects of its activity. Still, a number of studies are going on in developing PTEN inhibitors, which look promising and be biologically active. A specific inhibitor or activator can target $P T E N$, resulting in its inhibition/activation at pharmacological levels, which can be helpful in the treatment of Breast Cancer. A thorough insight into the PTEN pathway can further help us in the exploration of more developed and updated cancer therapies.

\section{Funding}

This research received no external funding.

\section{Acknowledgments}

The authors are obliged to Maharishi Markandeshwar (Deemed to be University) Mullana (Ambala) for providing the requisite platform to carry out this work.

\section{Conflicts of Interest}

The authors declare no conflict of interest.

\section{References}

1. Li, D.-M.; Sun, H. TEP1, encoded by a candidate tumor suppressor locus, is a novel protein tyrosine phosphatase regulated by transforming growth factor $\beta$. Cancer Research 1997, 57, 2124-2129. 
2. Liaw, D.; Marsh, D.J.; Li, J.; Dahia, P.L.; Wang, S.I.; Zheng, Z.; Bose, S.; Call, K.M.; Tsou, H.C.; Peacoke, M. Germline mutations of the PTEN gene in Cowden disease, an inherited breast and thyroid cancer syndrome. Nature Genetics 1997, 16, 64-67, https://doi.org/10.1038/ng0597-64.

3. Sharma, V.R.; Singh, M.; Kumar, V.; Yadav, M.; Sehrawat, N.; Sharma, D.K.; Sharma, A.K. Microbiome dysbiosis in cancer: Exploring therapeutic strategies to counter the disease. Seminars in Cancer Biology 2020, https://doi.org/10.1016/j.semcancer.2020.07.006.

4. Stiles, B.; Groszer, M.; Wang, S.; Jiao, J.; Wu, H. PTENless means more. Developmenta Biology 2004, 273, 175-184, https://doi.org/10.1016/j.ydbio.2004.06.008.

5. Engelman, J.A.; Luo, J.; Cantley, L.C. The evolution of phosphatidylinositol 3-kinases as regulators of growth and metabolism. Nature Reviews Genetics 2006, 7, 606-619, https://doi.org/10.1038/nrg1879.

6. Cully, M.; You, H.; Levine, A.J.; Mak, T.W. Beyond PTEN mutations: the PI3K pathway as an integrator of multiple inputs during tumorigenesis. Nature Reviews Cancer 2006, 6, 184-192, https://doi.org/10.1038/nrc1819.

7. Taylor, V.; Wong, M.; Brandts, C.; Reilly, L.; Dean, N.M.; Cowsert, L.M.; Moodie, S.; Stokoe, D. 5' phospholipid phosphatase SHIP-2 causes protein kinase B inactivation and cell cycle arrest in glioblastoma cells. Molecular and Cellular Biology 2000, 20, 6860-6871, https://doi.org/10.1128/mcb.20.18.68606871.2000.

8. Rajpoot, M.; Sharma, A.K.; Sharma, A.; Gupta, G.K. Understanding the microbiome: emerging biomarkers for exploiting the microbiota for personalized medicine against cancer. Seminars in Cancer Biology 2018, 52, 1-8, https://doi.org/10.1016/j.semcancer.2018.02.003.

9. Carrà G, Russo I, Guerrasio A, Morotti A. Nuclear-cytoplasmic Shuttling in Chronic Myeloid Leukemia: Implications in Leukemia Maintenance and Therapy. Cells. 2019;8(10):1248. doi:10.3390/cells8101248.

10. Xue X, Wang H, Su J. Inhibition of MiR-122 Decreases Cerebral Ischemia-reperfusion Injury by Upregulating DJ-1-Phosphatase and Tensin Homologue Deleted on Chromosome 10 (PTEN)/Phosphonosinol-3 Kinase $\quad$ (PI3K)/AKT. Med Sci Monit. 2020;26:e915825. doi:10.12659/MSM.915825.

11. Myers, M.P.; Pass, I.; Batty, I.H.; Van der Kaay, J.; Stolarov, J.P.; Hemmings, B.A.; Wigler, M.H.; Downes, C.P.; Tonks, N.K. The lipid phosphatase activity of PTEN is critical for its tumor supressor function. Proceedings of the National Academy of Sciences 1998, 95, 13513-13518, https://doi.org/10.1073/pnas.95.23.13513.

12. Sun, H.; Lesche, R.; Li, D.-M.; Liliental, J.; Zhang, H.; Gao, J.; Gavrilova, N.; Mueller, B.; Liu, X.; Wu, H. PTEN modulates cell cycle progression and cell survival by regulating phosphatidylinositol 3, 4, 5,trisphosphate and Akt/protein kinase B signaling pathway. Proceedings of the National Academy of Sciences 1999, 96, 6199-6204, https://doi.org/10.1073/pnas.96.11.6199.

13. Sharma, A.K.; Sharma, V.R.; Gupta, G.K.; Ashraf, G.M.; Kamal, M.A. Advanced Glycation End Products (AGEs), Glutathione and Breast Cancer: Factors, Mechanism and Therapeutic Interventions. Current Drug Metabolism 2019, 20, 65-71, https://doi.org/10.2174/1389200219666180912104342.

14. Stambolic, V.; Suzuki, A.; De La Pompa, J.L.; Brothers, G.M.; Mirtsos, C.; Sasaki, T.; Ruland, J.; Penninger, J.M.; Siderovski, D.P.; Mak, T.W. Negative regulation of PKB/Akt-dependent cell survival by the tumor suppressor PTEN. Cell 1998, 95, 29-39, https://doi.org/10.1016/s0092-8674(00)81780-8.

15. Nair, M.; Sandhu, S.S.; Sharma, A.K. Cancer molecular markers: A guide to cancer detection and management. Seminars in Cancer Biology 2018, 52, 39-55,https://doi.org/10.1016/j.semcancer.2018.02.002.

16. Neamah Zghair, A.; Kumar Sinha, D.; Kassim, A.; Alfaham, M.; Sharma, A.K. Differential gene expression of BRCA1, ERBB2 and TP53 biomarkers between human breast tissue and peripheral blood samples of breast cancer patients. Anti-Cancer Agents in Medicinal Chemistry (Formerly Current Medicinal ChemistryAnti-Cancer Agents) 2016, 16, 519-525, https://doi.org/10.2174/1871520615666150824150913.

17. Massagué, J. G1 cell-cycle control and cancer. Nature 2004, 432, 298-306, https://doi.org/10.1038/nature03094.

18. Sherr, C.J.; Roberts, J.M. CDK inhibitors: positive and negative regulators of G1-phase progression. Genes \& Development 1999, 13, 1501-1512, https://doi.org/10.1101/gad.13.12.1501.

19. Carrano, A.C.; Eytan, E.; Hershko, A.; Pagano, M. SKP2 is required for ubiquitin-mediated degradation of the CDK inhibitor p27. Nature Cell Biology 1999, 1, 193-199, https://doi.org/10.1038/12013.

20. Groszer, M.; Erickson, R.; Scripture-Adams, D.D.; Lesche, R.; Trumpp, A.; Zack, J.A.; Kornblum, H.I.; Liu, $\mathrm{X}$; $\mathrm{Wu}, \mathrm{H}$. Negative regulation of neural stem/progenitor cell proliferation by the Pten tumor suppressor gene in vivo. Science 2001, 294, 2186-2189, https://doi.org/10.1126/science.1065518.

21. Li, D.-M.; Sun, H. PTEN/MMAC1/TEP1 suppresses the tumorigenicity and induces G1 cell cycle arrest in human glioblastoma cells. Proceedings of the National Academy of Sciences 1998, 95, 15406-15411, https://doi.org/10.1073/pnas.95.26.15406.

22. Di Cristofano, A.; De Acetis, M.; Koff, A.; Cordon-Cardo, C.; Pandolfi, P.P. Pten and p27 KIP1 cooperate in prostate cancer tumor suppression in the mouse. Nature Genetics 2001, 27, 222-224, https://doi.org/10.1038/84879.

23. Goyal, K.; Sharma, A.; Arya, R.; Sharma, R.; Gupta, G.K.; Sharma, A.K. Double edge sword behavior of carbendazim: a potent fungicide with anticancer therapeutic properties. Anti-Cancer Agents in Medicinal 
Chemistry (Formerly Current Medicinal Chemistry-Anti-Cancer Agents) 2018, 18, 38-45, https://doi.org/10.2174/1871520616666161221113623.

24. Primo, L.M.; Teixeira, L.K. DNA replication stress: oncogenes in the spotlight. Genetics and Molecular Biology 2020, 43, https://doi.org/10.1590/1678-4685GMB-2019-0138.

25. Brandmaier, A.; Hou, S.-Q.; Shen, W.H. Cell Cycle Control by PTEN. Journal of Molecular Biology 2017, 429, 2265-2277, https://doi.org/10.1016/j.jmb.2017.06.004.

26. Liu, J.-L.; Sheng, X.; Hortobagyi, Z.K.; Mao, Z.; Gallick, G.E.; Yung, W.A. Nuclear PTEN-mediated growth suppression is independent of Akt down-regulation. Molecular and Cellular Biology 2005, 25, 6211-6224, https://doi.org/10.1128/MCB.25.14.6211-6224.2005.

27. Chang, C.-J.; Mulholland, D.J.; Valamehr, B.; Mosessian, S.; Sellers, W.R.; Wu, H. PTEN nuclear localization is regulated by oxidative stress and mediates p53-dependent tumor suppression. Molecular and Cellular Biology 2008, 28, 3281-3289, https://doi.org/10.1128/MCB.00310-08.

28. Chung, J.-H.; Eng, C. Nuclear-cytoplasmic partitioning of phosphatase and tensin homologue deleted on chromosome 10 (PTEN) differentially regulates the cell cycle and apoptosis. Cancer Research 2005, 65, 8096-8100, https://doi.org/10.1158/0008-5472.can-05-1888.

29. Li, A.G.; Piluso, L.G.; Cai, X.; Wei, G.; Sellers, W.R.; Liu, X. Mechanistic insights into maintenance of high p53 acetylation by PTEN. Molecular Cell 2006, 23, 575-587, https://doi.org/10.1016/j.molcel.2006.06.028.

30. Patel, R.; Gao, M.; Ahmad, I.; Fleming, J.; Singh, L.B.; Rai, T.S.; McKie, A.B.; Seywright, M.; Barnetson, R.J.; Edwards, J. Sprouty2, PTEN, and PP2A interact to regulate prostate cancer progression. The Journal of Clinical Investigation 2013, 123, 1157-1175, https://doi.org/10.1172/JCI63672.

31. He, J.; Kang, X.; Yin, Y.; Chao, K.C.; Shen, W.H. PTEN regulates DNA replication progression and stalled fork recovery. Nature Communications 2015, 6, 1-11, https://doi.org/10.1038/ncomms8620.

32. Wang, G.; Li, Y.; Wang, P.; Liang, H.; Cui, M.; Zhu, M.; Guo, L.; Su, Q.; Sun, Y.; McNutt, M.A. PTEN regulates RPA1 and protects DNA replication forks. Cell Research 2015, 25, 1189-1204, https://doi.org/10.1038/cr.2015.115.

33. Kandel, E.S.; Skeen, J.; Majewski, N.; Di Cristofano, A.; Pandolfi, P.P.; Feliciano, C.S.; Gartel, A.; Hay, N. Activation of Akt/protein kinase B overcomes a G2/M cell cycle checkpoint induced by DNA damage. Molecular and Cellular Biology 2002, 22, 7831-7841, https://doi.org/10.1128/MCB.22.22.7831-7841.2002.

34. Puc, J.; Keniry, M.; Li, H.S.; Pandita, T.K.; Choudhury, A.D.; Memeo, L.; Mansukhani, M.; Murty, V.V.; Gaciong, Z.; Meek, S.E. Lack of PTEN sequesters CHK1 and initiates genetic instability. Cancer Cell 2005, 7, 193-204, https://doi.org/10.1016/j.ccr.2005.01.009.

35. Martin, S.A.; Ouchi, T. Cellular commitment to re-entry into the cell cycle after stalled DNA is determined by site-specific phosphorylation of Chk1 and PTEN. Molecular Cancer Therapeutics 2008, 7, 2509-2516, https://doi.org/10.1158/1535-7163.MCT-08-0199.

36. Kim, S.; Lee, H.W.; Baek, J.; Cho, Y.; Kang, H.; Jeong, J.; Song, J.; Park, H.; Chun, K. Activation of nuclear PTEN by inhibition of Notch signaling induces G2/M cell cycle arrest in gastric cancer. Oncogene 2016, 35, 251-260, https://doi.org/10.1038/onc.2015.80.

37. Shinde, S.R.; Gangula, N.R.; Kavela, S.; Pandey, V.; Maddika, S. TOPK and PTEN participate in CHFR mediated mitotic checkpoint. Cellular Signalling 2013, 25, 2511-2517, https://doi.org/10.1016/j.cellsig.2013.08.013.

38. Kang, X.; Song, C.; Du, X.; Zhang, C.; Liu, Y.; Liang, L.; He, J.; Lamb, K.; Shen, W.H.; Yin, Y. PTEN stabilizes TOP2A and regulates the DNA decatenation. Scientific Reports 2015, 5, https://doi.org/10.1038/srep17873.

39. Leonard, M.; Hill, N.; Bubulya, P.; Kadakia, M. The PTEN-Akt pathway impacts the integrity and composition of mitotic centrosomes. Cell Cycle 2013, 12, 1406-1415, https://doi.org/10.4161/cc.24516.

40. Zhang, Z.; Hou, S.-Q.; He, J.; Gu, T.; Yin, Y.; Shen, W.H. PTEN regulates PLK1 and controls chromosomal stability during cell division. Cell Cycle 2016, 15, 2476-2485, https://doi.org/10.1080/15384101.2016.1203493.

41. Sheikh I, S.V., Singh H T, Aggarwal D, Sankhyan A, Vyas P, Sharma AK, and Bishayee A. Cancer chemoprevention by flavonoids, dietary polyphenols and terpenoids. Biointerface Research in Applied Chemistry 2020, 11, 8502-8537, https://doi.org/10.33263/BRIAC111.85028537.

42. Choi, B.; Chen, C.-Y.; Dai, W. Chromatin PTEN is involved in DNA damage response partly through regulating Rad52 sumoylation. Cell Cycle 2013, 12, 3442-3447, https://doi.org/10.4161/cc.26465.

43. Osaki, M.; Oshimura, M.A.; Ito, H. PI3K-Akt pathway: its functions and alterations in human cancer. Apoptosis 2004, 9, 667-676, https://doi.org/10.1023/b:appt.0000045801.15585.dd.

44. Song, M.S.; Salmena, L.; Pandolfi, P.P. The functions and regulation of the PTEN tumour suppressor. Nature Reviews Molecular Cell Biology 2012, 13, 283-296, https://doi.org/10.1038/nrm3330.

45. Hollander, M.C.; Blumenthal, G.M.; Dennis, P.A. PTEN loss in the continuum of common cancers, rare syndromes and mouse models. Nature Reviews Cancer 2011, 11, 289-301, https://doi.org/10.1038/nrc3037.

46. Sharma, A.K. Emerging trends in biomarker discovery: Ease of prognosis and prediction in cancer. Seminars in Cancer Biology 2018, 52, iii-iv, https://doi.org/10.1016/j.semcancer.2018.05.008. 
47. Sharma, V.R.; Sharma, A.K.; Sharma, D.K.; Mishra, N. New and potential therapies for the treatment of Breast Cancer: An update for oncologists. . CTBCR 2016, 6, 23-29.

48. Alimonti, A.; Carracedo, A.; Clohessy, J.G.; Trotman, L.C.; Nardella, C.; Egia, A.; Salmena, L.; Sampieri, K.; Haveman, W.J.; Brogi, E. Subtle variations in Pten dose determine cancer susceptibility. Nature Genetics 2010, 42, 454-458, https://doi.org/10.1038/ng.556.

49. Chen, C.-Y.; Chen, J.; He, L.; Stiles, B.L. PTEN: tumor suppressor and metabolic regulator. Frontiers in Endocrinology 2018, 9, https://doi.org/10.3389/fendo.2018.00338.

50. Stiles, B.L. PI-3-K and AKT: onto the mitochondria. Advanced Drug Delivery Reviews 2009, 61, 1276-1282, https://doi.org/10.1016/j.addr.2009.07.017.

51. Sano, H.; Kane, S.; Sano, E.; Mîinea, C.P.; Asara, J.M.; Lane, W.S.; Garner, C.W.; Lienhard, G.E. Insulinstimulated phosphorylation of a Rab GTPase-activating protein regulates GLUT4 translocation. Journal of Biological Chemistry 2003, 278, 14599-14602, https://doi.org/10.1074/jbc.C300063200.

52. Stiles, B.; Wang, Y.; Stahl, A.; Bassilian, S.; Lee, W.P.; Kim, Y.-J.; Sherwin, R.; Devaskar, S.; Lesche, R.; Magnuson, M.A. Liver-specific deletion of negative regulator Pten results in fatty liver and insulin hypersensitivity. Proceedings of the National Academy of Sciences 2004, 101, 2082-2087, https://doi.org/10.1073/pnas.0308617100.

53. Gross, D.N.; Wan, M.; Birnbaum, M.J. The role of FOXO in the regulation of metabolism. Current Diabetes Reports 2009, 9, 208-214, https://doi.org/10.1007/s11892-009-0034-5.

54. Xiong, S.; Salazar, G.; San Martin, A.; Ahmad, M.; Patrushev, N.; Hilenski, L.; Nazarewicz, R.R.; Ma, M.; Ushio-Fukai, M.; Alexander, R.W. PGC-1 $\alpha$ serine 570 phosphorylation and GCN5-mediated acetylation by angiotensin II drive catalase down-regulation and vascular hypertrophy. Journal of Biological Chemistry 2010, 285, 2474-2487, https://doi.org/10.1074/jbc.M109.065235.

55. Zghair, A.N,; Sharma, R.; K Sharma, A. Hormone responsive breast cancer and BRCA1 mutation: mechanism, regulation and iron-mediated effects. Current Pharmaceutical Biotechnology 2014, 15, 11131124, https://doi.org/10.2174/1389201015666141126120725.

56. Kurlawalla-Martinez, C.; Stiles, B.; Wang, Y.; Devaskar, S.U.; Kahn, B.B.; Wu, H. Insulin hypersensitivity and resistance to streptozotocin-induced diabetes in mice lacking PTEN in adipose tissue. Molecular and Cellular Biology 2005, 25, 2498-2510, https://doi.org/10.1128/MCB.25.6.2498-2510.2005.

57. Haeusler, R.A.; Hartil, K.; Vaitheesvaran, B.; Arrieta-Cruz, I.; Knight, C.M.; Cook, J.R.; Kammoun, H.L.; Febbraio, M.A.; Gutierrez-Juarez, R.; Kurland, I.J. Integrated control of hepatic lipogenesis versus glucose production requires FoxO transcription factors. Nature Communications 2014, 5, 1-8, https://doi.org/10.1038/ncomms6190.

58. Porstmann, T.; Santos, C.R.; Griffiths, B.; Cully, M.; Wu, M.; Leevers, S.; Griffiths, J.R.; Chung, Y.-L.; Schulze, A. SREBP activity is regulated by mTORC1 and contributes to Akt-dependent cell growth. Cell Metabolism 2008, 8, 224-236, https://doi.org/10.1016/j.cmet.2008.07.007.

59. Ram; Sharma, V.; Sheikh, I.; Sankhyan, A.; Aggarwal, D.; Sharma, A. Anti-cancer potential of natural products: recent trends, scope and relevance. Letters in Applied NanoBioScience 2020, 9, 902-907.

60. Yecies, J.L.; Zhang, H.H.; Menon, S.; Liu, S.; Yecies, D.; Lipovsky, A.I.; Gorgun, C.; Kwiatkowski, D.J.; Hotamisligil, G.S.; Lee, C.-H. Akt stimulates hepatic SREBP1c and lipogenesis through parallel mTORC1dependent and independent pathways. Cell Metabolism 2011, 14, 21-32, https://doi.org/10.1016/j.cmet.2011.06.002.

61. Sharma, A.; Ghani, A.; Sak, K.; Tuli, H.S.; Sharma, A.K.; Setzer, W.N.; Sharma, S.; Das, A.K. Probing into Therapeutic Anti-cancer Potential of Apigenin: Recent Trends and Future Directions. Recent Patents on Inflammation \& Allergy Drug Discovery 2019, https://doi.org/10.2174/1872213X13666190816160240.

62. Du, X.; Kristiana, I.; Wong, J.; Brown, A.J. Involvement of Akt in ER-to-Golgi transport of SCAP/SREBP: a link between a key cell proliferative pathway and membrane synthesis. Molecular Biology of the Cell 2006, 17, 2735-2745, https://doi.org/10.1091/mbc.e05-11-1094.

63. Sharma, V.R.; Gupta, G.K.; Sharma, A.K.; Batra, N.; Sharma, D.K.; Joshi, A.; Sharma, A.K. PI3K/Akt/mTOR Intracellular Pathway and Breast Cancer: Factors, Mechanism and Regulation. Current Pharmaceutical Design 2017, 23, 1633-1638, https://doi.org/10.2174/1381612823666161116125218.

64. Palian, B.M.; Rohira, A.D.; Johnson, S.A.; He, L.; Zheng, N.; Dubeau, L.; Stiles, B.L.; Johnson, D.L. Maf1 is a novel target of PTEN and PI3K signaling that negatively regulates oncogenesis and lipid metabolism. PLoS Genet 2014, 10, https://doi.org/10.1371/journal.pgen.1004789.

65. Varruchi Sharma, N.B.; Sharma, A.K. In-silico designed and optimized lead inhibiting breast cancer mTOR FRB domain substrate recruitment mechanism. IPO 2018.

66. Galicia, V.A.; He, L.; Dang, H.; Kanel, G.; Vendryes, C.; French, B.A.; Zeng, N.; Bayan, J.A.; Ding, W.; Wang, K.S. Expansion of hepatic tumor progenitor cells in Pten-null mice requires liver injury and is reversed by loss of AKT2. Gastroenterology 2010, 139, 2170-2182, https://doi.org/10.1053/j.gastro.2010.09.002.

67. Matsumoto, M.; Han, S.; Kitamura, T.; Accili, D. Dual role of transcription factor FoxO1 in controlling hepatic insulin sensitivity and lipid metabolism. The Journal of Clinical Investigation 2006, 116, 2464-2472, https://doi.org/10.1172/JCI27047. 
68. Gottlob, K.; Majewski, N.; Kennedy, S.; Kandel, E.; Robey, R.B.; Hay, N. Inhibition of early apoptotic events by Akt/PKB is dependent on the first committed step of glycolysis and mitochondrial hexokinase. Genes \& Development 2001, 15, 1406-1418, https://doi.org/10.1101/gad.889901.

69. Nair, M.; Singh Sandhu, S.; K Sharma, A. Prognostic and predictive biomarkers in cancer. Current Cancer Drug Targets 2014, 14, 477-504, https://doi.org/10.2174/1568009614666140506111118.

70. Arciuch, V.G.A.; Galli, S.; Franco, M.C.; Lam, P.Y.; Cadenas, E.; Carreras, M.C.; Poderoso, J.J. Akt1 intramitochondrial cycling is a crucial step in the redox modulation of cell cycle progression. PloS One 2009, 4, https://doi.org/10.1371/journal.pone.0007523.

71. Li, C.; Li, Y.; He, L.; Agarwal, A.R.; Zeng, N.; Cadenas, E.; Stiles, B.L. PI3K/AKT signaling regulates bioenergetics in immortalized hepatocytes. Free Radical Biology and Medicine 2013, 60, 29-40, https://doi.org/10.1016/j.freeradbiomed.2013.01.013.

72. Nadal, A.; Marrero, P.F.; Haro, D. Down-regulation of the mitochondrial 3-hydroxy-3-methylglutaryl-CoA synthase gene by insulin: the role of the forkhead transcription factor FKHRL1. Biochemical Journal 2002, 366, 289-297, https://doi.org/10.1042/BJ20020598.

73. Villena, J.A.; Kralli, A. ERR $\alpha$ : a metabolic function for the oldest orphan. Trends in Endocrinology \& Metabolism 2008, 19, 269-276, https://doi.org/10.1016/j.tem.2008.07.005.

74. Li, Y.; He, L.; Zeng, N.; Sahu, D.; Cadenas, E.; Shearn, C.; Li, W.; Stiles, B.L. Phosphatase and tensin homolog deleted on chromosome 10 (PTEN) signaling regulates mitochondrial biogenesis and respiration via estrogen-related receptor $\alpha(\mathrm{ERR} \alpha)$. Journal of Biological Chemistry 2013, 288, 25007-25024, https://doi.org/10.1074/jbc.M113.450353.

75. Piantadosi, C.A.; Suliman, H.B. Mitochondrial transcription factor A induction by redox activation of nuclear respiratory factor 1. Journal of Biological Chemistry 2006, 281, 324-333, https://doi.org/10.1074/jbc.M508805200.

76. Piao, Y.; Kim, H.G.; Oh, M.S.; Pak, Y.K. Overexpression of TFAM, NRF-1 and myr-AKT protects the MPP+-induced mitochondrial dysfunctions in neuronal cells. Biochimica et Biophysica Acta (BBA)-General Subjects 2012, 1820, 577-585, https://doi.org/10.1016/j.bbagen.2011.08.007.

77. Sharma, V.; Sharma, A.K.; Punj, V.; Priya, P. Recent nanotechnological interventions targeting PI3K/Akt/mTOR pathway: A focus on breast cancer. Seminars in Cancer Biology 2019, 59, 133-146, https://doi.org/10.1016/j.semcancer.2019.08.005.

78. Worby, C.A.; Dixon, J.E. Annual Review of Biochemistry. PTEN 2014, 83, 641-669, https://doi.org/10.1146/annurev-biochem-082411-113907.

79. Naderali, E.; Khaki, A.A.; Rad, J.S.; Ali-Hemmati, A.; Rahmati, M.; Charoudeh, H.N. Regulation and modulation of PTEN activity. Molecular Biology Reports 2018, 45, 2869-2881, https://doi.org/10.1007/s11033-018-4321-6.

80. García, J.M.; Silva, J.; Pena, C.; Garcia, V.; Rodríguez, R.; Cruz, M.A.; Cantos, B.; Provencio, M.; Espana, P.; Bonilla, F. Promoter methylation of the PTEN gene is a common molecular change in breast cancer. Genes, Chromosomes and Cancer 2004, 41, 117-124, https://doi.org/10.1002/gcc.20062.

81. Wang, X.; Jiang, X. Post-translational regulation of PTEN. Oncogene 2008, 27, 5454-5463, https://doi.org/10.1038/onc.2008.242.

82. Cordier, F.; Chaffotte, A.; Terrien, E.; Préhaud, C.; Theillet, F.O.-X.; Delepierre, M.; Lafon, M.; Buc, H.; Wolff, N. Ordered phosphorylation events in two independent cascades of the PTEN C-tail revealed by NMR. Journal of the American Chemical Society 2012, 134, 20533-20543, https://doi.org/10.1021/ja310214g.

83. Yang, Z.; Yuan, X.-G.; Chen, J.; Luo, S.-W.; Luo, Z.-J.; Lu, N.-H. Reduced expression of PTEN and increased PTEN phosphorylation at residue Ser380 in gastric cancer tissues: a novel mechanism of PTEN inactivation. Clinics and Research in Hepatology and Gastroenterology 2013, 37, 72-79, https://doi.org/10.1016/j.clinre.2012.03.002.

84. Xu, W.-T.; Yang, Z.; Lu, N.-H. Roles of PTEN (Phosphatase and Tensin Homolog) in gastric cancer development and progression. Asian Pacific Journal of Cancer Previews 2014, 15, 17-24, https://doi.org/10.7314/apjcp.2014.15.1.17.

85. Rahdar, M.; Inoue, T.; Meyer, T.; Zhang, J.; Vazquez, F.; Devreotes, P.N. A phosphorylation-dependent intramolecular interaction regulates the membrane association and activity of the tumor suppressor PTEN. Proceedings of the National Academy of Sciences 2009, 106, 480-485, https://doi.org/10.1073/pnas.0811212106.

86. Jang, H.D.; Noh, J.Y.; Shin, J.H.; Lin, J.J.; Lee, S.Y. PTEN regulation by the Akt/GSK-3 $\beta$ axis during RANKL signaling. Bone 2013, 55, 126-131, https://doi.org/10.1016/j.bone.2013.02.005.

87. Odriozola, L.; Singh, G.; Hoang, T.; Chan, A.M. Regulation of PTEN activity by its carboxyl-terminal autoinhibitory domain. Journal of Biological Chemistry 2007, 282, 23306-23315, https://doi.org/10.1074/jbc.M611240200.

88. Li, Z.; Dong, X.; Wang, Z.; Liu, W.; Deng, N.; Ding, Y.; Tang, L.; Hla, T.; Zeng, R.; Li, L. Regulation of PTEN by Rho small GTPases. Nature Cell Biology 2005, 7, 399-404, https://doi.org/10.1038/ncb1236.

89. Papakonstanti, E.A.; Ridley, A.J.; Vanhaesebroeck, B. The p110 1 isoform of PI 3-kinase negatively controls RhoA and PTEN. The EMBO Journal 2007, 26, 3050-3061, https://doi.org/10.1038/sj.emboj.7601763. 
90. Yim, E.-K.; Peng, G.; Dai, H.; Hu, R.; Li, K.; Lu, Y.; Mills, G.B.; Meric-Bernstam, F.; Hennessy, B.T.; Craven, R.J. Rak functions as a tumor suppressor by regulating PTEN protein stability and function. Cancer cell 2009, 15, 304-314, https://doi.org/10.1016/j.ccr.2009.02.012.

91. Yan Chunchi, Minmeng Zhao, Shuo Li, Tongjun Liu, Cheng Xu, Long Liu, Tuoyu Geng, Daoqing Gong, Increase of E3 ubiquitin-ligase NEDD4 expression leads to degradation of its target proteins PTEN/IGF1R during the formation of goose fatty liver,Journal of Animal Science, , skaa270, https://doi.org/10.1093/jas/skaa270.

92. Wang, X.; Trotman, L.C.; Koppie, T.; Alimonti, A.; Chen, Z.; Gao, Z.; Wang, J.; Erdjument-Bromage, H.; Tempst, P.; Cordon-Cardo, C. NEDD4-1 is a proto-oncogenic ubiquitin ligase for PTEN. Cell 2007, 128, 129-139, https://doi.org/10.1016/j.cell.2006.11.039.

93. Fouladkou, F.; Landry, T.; Kawabe, H.; Neeb, A.; Lu, C.; Brose, N.; Stambolic, V.; Rotin, D. The ubiquitin ligase Nedd4-1 is dispensable for the regulation of PTEN stability and localization. Proceedings of the National Academy of Sciences 2008, 105, 8585-8590, https://doi.org/10.1073/pnas.0803233105.

94. Van Themsche, C.; Leblanc, V.; Parent, S.; Asselin, E. X-linked inhibitor of apoptosis protein (XIAP) regulates PTEN ubiquitination, content, and compartmentalization. Journal of Biological Chemistry 2009, 284, 20462-20466, https://doi.org/10.1074/jbc.C109.009522.

95. Tolkacheva, T.; Boddapati, M.; Sanfiz, A.; Tsuchida, K.; Kimmelman, A.C.; Chan, A.M. Regulation of PTEN binding to MAGI-2 by two putative phosphorylation sites at threonine 382 and 383. Cancer research 2001, 61, 4985-4989.

96. Gupta, A.; Leslie, N.R. Controlling PTEN (Phosphatase and Tensin Homolog) Stability A Dominant Role For Lysine 66. Journal of Biological Chemistry 2016, 291, 18465-18473, https://doi.org/10.1074/jbc.M116.727750.

97. Sehrawat, N.; Yadav, M.; Singh, M.; Kumar, V.; Sharma, V.R.; Sharma, A.K. Probiotics in microbiome ecological balance providing a therapeutic window against cancer. Seminars in Cancer Biology 2020, https://doi.org/10.1016/j.semcancer.2020.06.009.

98. Song, M.S.; Salmena, L.; Carracedo, A.; Egia, A.; Lo-Coco, F.; Teruya-Feldstein, J.; Pandolfi, P.P. The deubiquitinylation and localization of PTEN are regulated by a HAUSP-PML network. Nature 2008, 455, 813-817, https://doi.org/10.1038/nature07290.

99. Mazza, M.; Pelicci, P. Is PML a Tumor Suppressor? Frontiers in Oncology 2013, 3, https://doi.org/10.3389/fonc.2013.00174.

100. Huang, J.; Yan, J.; Zhang, J.; Zhu, S.; Wang, Y.; Shi, T.; Zhu, C.; Chen, C.; Liu, X.; Cheng, J. SUMO1 modification of PTEN regulates tumorigenesis by controlling its association with the plasma membrane. Nature Communications 2012, 3, 1-12, https://doi.org/10.1038/ncomms1919.

101. Bassi, C.; Ho, J.; Srikumar, T.; Dowling, R.; Gorrini, C.; Miller, S.; Mak, T.; Neel, B.; Raught, B.; Stambolic, V. Nuclear PTEN controls DNA repair and sensitivity to genotoxic stress. Science 2013, 341, 395-399, https://doi.org/10.1126/science.1236188.

102. Okumura, K.; Mendoza, M.; Bachoo, R.M.; DePinho, R.A.; Cavenee, W.K.; Furnari, F.B. PCAF modulates PTEN activity. Journal of Biological Chemistry 2006, 281, 26562-26568, https://doi.org/10.1074/jbc.M605391200.

103. Ding, L.; Chen, S.; Liu, P.; Pan, Y.; Zhong, J.; Regan, K.M.; Wang, L.; Yu, C.; Rizzardi, A.; Cheng, L. CBP loss cooperates with PTEN haploinsufficiency to drive prostate cancer: implications for epigenetic therapy. Cancer Research 2014, 74, 2050-2061, https://doi.org/10.1158/0008-5472.CAN-13-1659.

104. Ross, S.H.; Lindsay, Y.; Safrany, S.T.; Lorenzo, O.; Villa, F.; Toth, R.; Clague, M.J.; Downes, C.P.; Leslie, N.R. Differential redox regulation within the PTP superfamily. Cellular Signalling 2007, 19, 1521-1530, https://doi.org/10.1016/j.cellsig.2007.01.026.

105. Zhang Y, Park J, Han SJ, et al. Redox regulation of tumor suppressor PTEN in cell signaling. Redox Biol. 2020;34:101553. doi:10.1016/j.redox.2020.101553.

106. Kwon, J.; Lee, S.-R.; Yang, K.-S.; Ahn, Y.; Kim, Y.J.; Stadtman, E.R.; Rhee, S.G. Reversible oxidation and inactivation of the tumor suppressor PTEN in cells stimulated with peptide growth factors. Proceedings of the National Academy of Sciences 2004, 101, 16419-16424, https://doi.org/10.1073/pnas.0407396101.

107. Figueiredo AM, Villacampa P, Diéguez-Hurtado R, et al. Phosphoinositide 3-Kinase-Regulated Pericyte Maturation Governs Vascular Remodeling. Circulation. 2020;142(7):688-704. doi:10.1161/CIRCULATIONAHA.119.042354.

108. Cao, J.; Schulte, J.; Knight, A.; Leslie, N.R.; Zagozdzon, A.; Bronson, R.; Manevich, Y.; Beeson, C.; Neumann, C.A. Prdx1 inhibits tumorigenesis via regulating PTEN/AKT activity. The EMBO Journal 2009, 28, 1505-1517, https://doi.org/10.1038/emboj.2009.101.

109. Kim, Y.-C.; Kitaura, H.; Taira, T.; Iguchi-Ariga, S.M.; Ariga, H. Oxidation of DJ-1-dependent cell transformation through direct binding of DJ-1 to PTEN. International journal of oncology 2009, 35, 13311341.

110. Shen, Y.H.; Zhang, L.; Gan, Y.; Wang, X.; Wang, J.; LeMaire, S.A.; Coselli, J.S.; Wang, X.L. Up-regulation of PTEN (phosphatase and tensin homolog deleted on chromosome ten) mediates p38 MAPK stress signalinduced inhibition of insulin signaling A cross-talk between stress signaling and insulin signaling in resistin- 
treated human endothelial cells. Journal of Biological Chemistry 2006, 281, 7727-7736, https://doi.org/10.1074/jbc.M511105200.

111. Uygur, B.; Abramo, K.; Leikina, E.; Vary, C.; Liaw, L.; Wu, W.S. SLUG is a direct transcriptional repressor of PTEN tumor suppressor. The Prostate 2015, 75, 907-916, https://doi.org/10.1002/pros.22974.

112. Hettinger, K.; Vikhanskaya, F.; Poh, M.; Lee, M.; De Belle, I.; Zhang, J.; Reddy, S.; Sabapathy, K. c-Jun promotes cellular survival by suppression of PTEN. Cell Death \& Differentiation 2007, 14, 218-229, https://doi.org/10.1038/sj.cdd.4401946.

113. Whelan, J.T.; Forbes, S.L.; Bertrand, F.E. CBF-1 (RBP-Jk) binds to the PTEN promoter and regulates PTEN gene expression. Cell Cycle 2007, 6, 80-84, https://doi.org/10.4161/cc.6.1.3648.

114. Olive, V.; Jiang, I.; He, L. mir-17-92, a cluster of miRNAs in the midst of the cancer network. The International Journal of Biochemistry \& Cell Biology 2010, 42, 1348-1354, https://doi.org/10.1016/j.biocel.2010.03.004.

115. He B, Zhao Z, Cai Q, et al. miRNA-based biomarkers, therapies, and resistance in cancer. Int J Biol Sci. 2020;16(14):2628-2647. Published 2020 Jul 19. doi:10.7150/ijbs.47203.

116. Jin, H.Y.; Oda, H.; Lai, M.; Skalsky, R.L.; Bethel, K.; Shepherd, J.; Kang, S.G.; Liu, W.H.; Sabouri-Ghomi, M.; Cullen, B.R. MicroRNA-17 92 plays a causative role in lymphomagenesis by coordinating multiple oncogenic pathways. The EMBO Journal 2013, 32, 2377-2391, https://doi.org/10.1038/emboj.2013.178.

117. Johnsson, P.; Ackley, A.; Vidarsdottir, L.; Lui, W.-O.; Corcoran, M.; Grandér, D.; Morris, K.V. A pseudogene long-noncoding-RNA network regulates PTEN transcription and translation in human cells. Nature Structural \& Molecular Biology 2013, 20, 440-446, https://doi.org/10.1038/nsmb.2516.

118. Poliseno, L.; Salmena, L.; Zhang, J.; Carver, B.; Haveman, W.J.; Pandolfi, P.P. A coding-independent function of gene and pseudogene mRNAs regulates tumour biology. Nature 2010, 465, 1033-1038, https://doi.org/10.1038/nature09144.

119. Sumazin, P.; Yang, X.; Chiu, H.-S.; Chung, W.-J.; Iyer, A.; Llobet-Navas, D.; Rajbhandari, P.; Bansal, M.; Guarnieri, P.; Silva, J. An extensive microRNA-mediated network of RNA-RNA interactions regulates established oncogenic pathways in glioblastoma. Cell 2011, 147, 370-381, https://doi.org/10.1016/j.cell.2011.09.041.

120. Cao, J.; Wan, L.; Hacker, E.; Dai, X.; Lenna, S.; Jimenez-Cervantes, C.; Wang, Y.; Leslie, N.R.; Xu, G.X.; Widlund, H.R. MC1R is a potent regulator of PTEN after UV exposure in melanocytes. Molecular Cell 2013, 51, 409-422, https://doi.org/10.1016/j.molcel.2013.08.010.

121. Wu, X.; Hepner, K.; Castelino-Prabhu, S.; Do, D.; Kaye, M.B.; Yuan, X.-J.; Wood, J.; Ross, C.; Sawyers, C.L.; Whang, Y.E. Evidence for regulation of the PTEN tumor suppressor by a membrane-localized multiPDZ domain containing scaffold protein MAGI-2. Proceedings of the National Academy of Sciences 2000, 97, 4233-4238, https://doi.org/10.1073/pnas.97.8.4233.

122. Lima-Fernandes, E.; Enslen, H.; Camand, E.; Kotelevets, L.; Boularan, C.; Achour, L.; Benmerah, A.; Gibson, L.C.; Baillie, G.S.; Pitcher, J.A. Distinct functional outputs of PTEN signalling are controlled by dynamic association with $\beta$-arrestins. The EMBO Journal 2011, 30, 2557-2568, https://doi.org/10.1038/emboj.2011.178.

123. Takahashi, Y.; Morales, F.C.; Kreimann, E.L.; Georgescu, M.M. PTEN tumor suppressor associates with NHERF proteins to attenuate PDGF receptor signaling. The EMBO Journal 2006, 25, 910-920, https://doi.org/10.1038/sj.emboj.7600979.

124. Van Diepen, M.T.; Parsons, M.; Downes, C.P.; Leslie, N.R.; Hindges, R.; Eickholt, B.J. MyosinV controls PTEN function and neuronal cell size. Nature Cell Biology 2009, 11, 1191-1196, https://doi.org/10.1038/ncb1961.

125. Cotter, L.; Özçelik, M.; Jacob, C.; Pereira, J.A.; Locher, V.; Baumann, R.; Relvas, J.B.; Suter, U.; Tricaud, N. Dlg1-PTEN interaction regulates myelin thickness to prevent damaging peripheral nerve overmyelination. Science 2010, 328, 1415-1418, https://doi.org/10.1126/science.1187735.

126. Rabinovsky, R.; Pochanard, P.; McNear, C.; Brachmann, S.M.; Duke-Cohan, J.S.; Garraway, L.A.; Sellers, W.R. p85 Associates with unphosphorylated PTEN and the PTEN-associated complex. Molecular and Cellular Biology 2009, 29, 5377-5388, https://doi.org/10.1128/MCB.01649-08.

127. Taniguchi, C.M.; Winnay, J.; Kondo, T.; Bronson, R.T.; Guimaraes, A.R.; Alemán, J.O.; Luo, J.; Stephanopoulos, G.; Weissleder, R.; Cantley, L.C. The phosphoinositide 3-kinase regulatory subunit p85 $\alpha$ can exert tumor suppressor properties through negative regulation of growth factor signaling. Cancer Research 2010, 70, 5305-5315, https://doi.org/10.1158/0008-5472.can-09-3399.

128. Valiente, M.; Andrés-Pons, A.; Gomar, B.; Torres, J.; Gil, A.; Tapparel, C.; Antonarakis, S.E.; Pulido, R. Binding of PTEN to specific PDZ domains contributes to PTEN protein stability and phosphorylation by microtubule-associated serine/threonine kinases. Journal of Biological Chemistry 2005, 280, 28936-28943, https://doi.org/10.1074/jbc.M504761200.

129. Fine, B.; Hodakoski, C.; Koujak, S.; Su, T.; Saal, L.H.; Maurer, M.; Hopkins, B.; Keniry, M.; Sulis, M.L.; Mense, S. Activation of the PI3K pathway in cancer through inhibition of PTEN by exchange factor PREX2a. Science 2009, 325, 1261-1265, https://doi.org/10.1126/science.1173569. 
130. He, L.; Ingram, A.; Rybak, A.P.; Tang, D. Shank-interacting protein-like 1 promotes tumorigenesis via PTEN inhibition in human tumor cells. The Journal of Clinical Investigation 2010, 120, 2094-2108, https://doi.org/10.1172/JCI40778.

131. He, L.; Fan, C.; Kapoor, A.; Ingram, A.J.; Rybak, A.P.; Austin, R.C.; Dickhout, J.; Cutz, J.-C.; Scholey, J.; Tang, D. $\alpha$-Mannosidase 2C1 attenuates PTEN function in prostate cancer cells. Nature Communications 2011, 2, 1-11, https://doi.org/10.1038/ncomms1309.

132. Salmena, L.; Carracedo, A.; Pandolfi, P.P. Tenets of PTEN tumor suppression. Cell 2008, 133, 403-414, https://doi.org/10.1016/j.cell.2008.04.013.

133. Bennett, K.L.; Mester, J.; Eng, C. Germline epigenetic regulation of KILLIN in Cowden and Cowden-like syndrome. Jama 2010, 304, 2724-2731, https://doi.org/10.1001/jama.2010.1877.

134. Cho, Y.-j.; Liang, P. Killin is a p53-regulated nuclear inhibitor of DNA synthesis. Proceedings of the National Academy of Sciences 2008, 105, 5396-5401, https://doi.org/10.1073/pnas.0705410105.

135. Zheng S, Wang S, Zhang Q, Zhang Z, Xu S. Avermectin inhibits neutrophil extracellular traps release by activating PTEN demethylation to negatively regulate the PI3K-ERK pathway and reducing respiratory burst in carp. Journal of Hazard Mater. 2020, 389, 121885, https://doi.org/10.1016/j.jhazmat.2019.121885. 